\title{
Article \\ The Impact of Agricultural Use of Retisols on the Molecular Structure of Humic Substances
}

\author{
Evgeny Lodygin $1, *(\mathbb{D})$ and Evgeny Abakumov ${ }^{2} \mathbb{C}$ \\ 1 Institute of Biology, Komi Science Center, Ural Branch, Russian Academy of Sciences, \\ 167982 Syktyvkar, Russia \\ 2 Department of Applied Ecology, Faculty of Biology, Saint Petersburg State University, \\ 199178 St. Petersburg, Russia; e_abakumov@mail.ru \\ * Correspondence: lodigin@ib.komisc.ru or e.abakumov@spbu.ru
}

Citation: Lodygin, E.; Abakumov, E. The Impact of Agricultural Use of Retisols on the Molecular Structure of Humic Substances. Agronomy 2022, 12, 144. https://doi.org/10.3390/ agronomy12010144

Academic Editor: Diego Pizzeghello

Received: 1 December 2021

Accepted: 1 January 2022

Published: 7 January 2022

Publisher's Note: MDPI stays neutral with regard to jurisdictional claims in published maps and institutional affiliations.

Copyright: (c) 2022 by the authors. Licensee MDPI, Basel, Switzerland. This article is an open access article distributed under the terms and conditions of the Creative Commons Attribution (CC BY) license (https:// creativecommons.org/licenses/by/ $4.0 /)$.

\begin{abstract}
Agricultural soil use does not only affect the amount of soil organic matter, but also the molecular composition of humic (HAs) and fulvic acids (FAs). Changed hydrothermal conditions and composition of the incoming plant residues are reflected in the rate of humification and its products. The objective of this study was to compare the molecular composition of HAs and FAs isolated from Eutric Albic Stagnic Histic Retisol (Loamic), two Eutric Albic Retisols (Loamic)—mature and arable. Plots of mature Retisols are located at a middle taiga (Komi Republic, Russia) in a bilberry-green-moss birch-spruce forest. The plot of Retisols arable is located in the fields of the Syktyvkar state farm, which is $3.3 \mathrm{~km}$ northeast of mature Retisol plots. The development period is about 40 years, it is sowed with a pea-oat mixture. The results obtained indicate that soil reclamation essentially increases the proportion of aromatic components and decreases the content of carboxyl and ester groups in the humic substance (HS) structure. An increased extent of hydromorphism of Retisols leads to the enrichment of HS with aliphatic fragments.
\end{abstract}

Keywords: arable soils; humic and fulvic acids; NMR spectroscopy

\section{Introduction}

The carbon cycle disequilibrium is a key challenge to humanity in the 21st century. An increased concentration of $\mathrm{CO}_{2}$ in the atmosphere and dehumidification of soils are interrelated phenomena and the most typical attributes of anthropogenic disturbances in the global carbon cycle. Therefore, achieving a balance between the emission of carbon dioxide and its absorption through both lower anthropogenic emissions and higher biotic runoff and replenishment of global stocks of soil organic carbon (SOC) is considered the main focus in the strategy for minimizing disturbances to the Earth's climatic system. The SOC increment rates and limits depend not merely on the quantity and quality of the incoming organic matter, but also on the stabilization of organic components in the soil [1]. For this reason, the information about soil organic matter (SOM) stability is of considerable importance for understanding processes occurring in the biosphere.

In recent years, several articles have questioned the role and even existence of soil humic substances (HS) as a distinct entity in SOM [2]. They are dealt with questions of $\mathrm{SOM}$ as a continuum of degradation reactions by unspecified processes from the original biomass inputs to carboxylic acids, and eventually to carbon dioxide without the formation of new classes of compounds along the way.

However, most reputable researchers in the field of HS chemistry fundamentally disagree with these views and highlight errors, misconceptions, misinterpretations, lack of scientific rigor, and failure to consider works and evidence that run counter to their preconceived views [3,4].

We believe that this complex matter (in both literal and figurative senses) could benefit from better cooperation between all scientific disciplines devoted to soil studies. Rather 
than abandoning the term "HS", as provocatively suggested by Lehmann and Kleber [2], we propose considering HS as a prominent agent of the soil ecosystem, which adequately mirrors the evolution of SOM depending on the changing environment.

Many articles have been focused on the impact of agricultural soil use on humus composition and properties [5-7]. The findings of these studies highlight the degree of transformation of soil humus under the influence of plowing, organic and mineral fertilizers, liming and crop cultivation. However, most of these studies are only cut down to the determination of the total amount of carbon and nitrogen or the analysis of the group and fractional composition of humus. There are significantly fewer articles devoted to the study of the transformation of the molecular composition of HS affected by agriculture. In recent years, the issue of improving the methodological approaches to the study of HS has been quite acute. Traditional research methods (the analysis of the group and fractional composition of humus, etc.) have largely exhausted their potential, and a number of structural research methods widely used in biochemistry turned out to be either difficult to be applied, or too indirect and difficult to interpret, which restricts their widespread use. For further development of HS biochemistry, it is necessary to reach a new level of methodological support associated with the use of modern direct methods for studying the molecular structure and functional properties of HS [8,9].

At present, the use of modern physicochemical research methods has made a more detailed study of the HS molecule structure possible, without a need to resort to molecule destruction. Methods such as IR, NMR, and EPR spectroscopy can provide extensive information not only about the qualitative set of the most important atomic groups and types of bonds, but also about the specific arrangement of individual functional groups and molecular fragments [10]. These physicochemical methods allow studying not merely diluted preparations or dry matter, but also compounds in an intermediate state (such as colloids or gels). A huge advantage of these methods lies in the potential to examine both HS and organogenic (peat or histic-like) horizons or soils in general, without exposing the studied object to any treatment, except for grinding. It permits tackling the problem of the correspondence between HS preparations and native substances, which are part of the unchanged soil composition [11-15]. Advances in the technology of the NMR method have made it possible to use it to study SOM in general and HS in particular. The use of superconducting magnets and Fourier transforms has not only made it possible to calculate the integral signal intensity, but also to separate signals when they are superimposed or exposed to a high noise level [16]. These methodological improvements allow is greater accuracy in quantitative estimates (with lower acquisition time). To obtain spectra of solid matters, the solid-phase method CPMAS (Cross-Polarization Magic-Angle Spinning) a technique with sample rotation at a magic angle- - has been developed [17-19]. The advantage of acquiring spectra in a solid-state is the possibility of introducing much more carbon in the sample probe (better signal-to-noise ratio at the same acquisition time). Furthermore, insoluble macromolecular substances (e.g., HS) can be studied, and it is not necessary to find a suitable solvent for the sample, if any.

The aim of this work was to compare the molecular composition of humic (HAs) and fulvic acids (FAs) isolated from mature and arable Retisols by means of ${ }^{13} \mathrm{C}$ NMR spectroscopic analysis.

\section{Materials and Methods}

Preparations of HAs and FAs were extracted from organogenic horizons of Eutric Albic Stagnic Histic Retisol (Loamic), two Eutric Albic Retisols (Loamic)—mature and arable. Plots of mature soils are laid on the catena: Eutric Albic Retisols (Loamic) and Eutric Albic Stagnic Histic Retisol (Loamic). The high position of the catena in the relief makes it possible to assess the effect of the moisture degree on the acid-base properties of HSs. The Eutric Albic Retisol (Loamic) plot is located at a distance of $8 \mathrm{~km}$ west of the city of Syktyvkar (Komi Republic, Russia) on the top of a watershed hill at the back of a microdepression of $1.5 \mathrm{~m}$ low $\left(61^{\circ} 39^{\prime} 44.6^{\prime \prime} \mathrm{N}, 50^{\circ} 41^{\prime} 10.4^{\prime \prime} \mathrm{E} ; 160 \mathrm{~m}\right.$ a.s.l.). The vegetation 
is a bilberry-green-moss birch-spruce forest with many fallen trees. The Eutric Albic Stagnic Histic Retisol (Loamic) plot is located at a distance of $74 \mathrm{~m}$ from the previous one $\left(61^{\circ} 39^{\prime} 42.4^{\prime \prime} \mathrm{N}, 50^{\circ} 41^{\prime} 8.4^{\prime \prime} \mathrm{E} ; 155 \mathrm{~m}\right.$ a.s.l.). It is a microhollow between low and flat elevations. The vegetation is a long moss-sphagnum birch-spruce forest. Near the plot, there is a sphagnum cover. The plot of Eutric Albic Retisols (Loamic) arable is located in the fields of the Syktyvkar state farm, which is $5 \mathrm{~km}$ southwest of Syktyvkar, on the watershed of the Sysola and Vazhel-yu rivers $\left(61^{\circ} 38^{\prime} 46.1^{\prime \prime} \mathrm{N}, 50^{\circ} 44^{\prime} 20.7^{\prime \prime} \mathrm{E} ; 145 \mathrm{~m}\right.$ a. s. 1.). The terrain is flat, with small hills. The development period is about 40 years. The plot is drained by a covered drainage system. It is sowed with a pea-oat mixture.

The ground soil sample was dried to an air-dry state and extracted with a mixture of $0.1 \mathrm{M} \mathrm{NaOH}$ and $0.1 \mathrm{M} \mathrm{Na}_{4} \mathrm{P}_{2} \mathrm{O}_{7}$ solutions. A solution of $\mathrm{Na}_{2} \mathrm{SO}_{4}(\omega=20 \%)$ was added to the alkaline extract to coagulate colloidal particles and were then centrifuged at $10,621 \times g$ for $5 \mathrm{~h}$. Furthermore, HAs were precipitated with a solution of $0.1 \mathrm{M} \mathrm{H}_{2} \mathrm{SO}_{4}$. FAs were purified on activated carbon AG-3 (JSC Sorbent, Perm, Russia) and desalted by passing through KU-2 cationite (Ural Chemical Company, Chelyabinsk, Russia) in $\mathrm{H}^{+}$-form.

The elemental composition of HAs was determined on the CHNSO-analyzer EA 1110 (Carlo-Erba, Milan, Italy) at the Chromatography Core Facility Center of the Institute of Biology, Komi Scientific Center, Ural Branch of the Russian Academy of Sciences. The mass fraction of oxygen was calculated based on the difference taking the total content of $C, N$, $\mathrm{H}, \mathrm{O}$ as $100 \%$. All calculations of the elemental composition of HAs and FAs were corrected to absolutely dry and ash-free preparations. The oxidation degree of HA was calculated according to the following formula: $\omega=(2 x(\mathrm{O})+3 x(\mathrm{~N})-x(\mathrm{H})): x(\mathrm{C})$ [7].

${ }^{13} \mathrm{C}$ NMR spectra of HS preparations were recorded on a pulsed NMR spectrometer Bruker CXP-100 with an operating frequency of $25.18 \mathrm{MHz}$ using the CPMAS solid-phase method (cross-polarization with rotation at a magic angle). The sample rotation frequency was $12.5 \mathrm{kHz}$, the contact time was $2 \mathrm{~ms}$, the relaxation time was $2 \mathrm{~s}$, the number of accumulations was up to 4000 scans. Chemical shifts are presented with regard to tetramethylsilane with a shift of $0 \mathrm{ppm}$. To standardize the quantitative characteristics of macromolecules, the ratio of carbon of aromatic structures to the carbon of aliphatic chains was used as a formal indicator $[20,21]$. In this case, the signals generated by aromatic structures were summarized by us in the range of 108-164 and 183-190 ppm, aliphatic ones-in the range of 0-108 and 164-183 ppm. Statistical processing of the results was performed with the Statistica 12 software package.

\section{Results}

${ }^{13} \mathrm{C}$ NMR spectroscopy method allows the identification of various functional groups and molecular fragments in the HS composition (Table 1).

Table 1. ${ }^{13} \mathrm{CNMR}$ chemical shifts of molecular groups and fragments of humic substances.

\begin{tabular}{cc}
\hline Chemical Shift, ppm & Molecular Groups and Fragments \\
\hline $0-47$ & Aliphatic $-\mathrm{CH},-\mathrm{CH}_{2}$, and $-\mathrm{CH}_{3}$ groups \\
$47-60$ & Amino group $\mathrm{C}$ and $-\mathrm{O}-\mathrm{CH}_{3}$ structures \\
$60-108$ & Carbohydrate, alcohol, and ether $-\mathrm{C}-\mathrm{O}$ groups \\
$108-144$ & Aromatic $\mathrm{C}_{\mathrm{Ar}}$ \\
$144-164$ & Phenol $\mathrm{C}_{\mathrm{Ar}}-\mathrm{O}$ \\
$164-183$ & Carboxyl $\mathrm{C}$ \\
$183-190$ & Quinone $\mathrm{C}_{\mathrm{Ar}}=\mathrm{O}$ \\
$190-204$ & Aldehyde and ketone $-\mathrm{C}=\mathrm{O}$ groups \\
\hline
\end{tabular}

The relative content of carbon atoms of the main functional groups and molecular fragments of HA and FA was estimated by integrating absorption lines in the corresponding ranges of chemical shifts. The results obtained are shown in Table 2. 
Table 2. Percentage of carbon in the main structural fragments of humic substances (according to ${ }^{13} \mathrm{C}$ NMR data).

\begin{tabular}{|c|c|c|c|c|c|c|c|c|c|c|c|}
\hline \multirow{2}{*}{ Horizon } & \multirow{2}{*}{$\begin{array}{l}\text { HS } \\
\text { Type }\end{array}$} & \multicolumn{8}{|c|}{ Chemical Shift, ppm } & \multirow{2}{*}{$\frac{\Sigma}{\Sigma} \frac{\mathrm{C}_{\mathrm{Ar}}}{\mathrm{C}_{\mathrm{AL}}}$} & \multirow{2}{*}{$\underset{\%}{\text { Aromaticity }}$} \\
\hline & & $0-47$ & $47-60$ & $60-108$ & $108-144$ & 144-164 & 164-183 & 183-190 & 190-204 & & \\
\hline \multicolumn{12}{|c|}{ Eutric Albic Retisols (Loamic) } \\
\hline \multirow{2}{*}{$\mathrm{O}$} & HAs & 22.4 & 8.1 & 12.8 & 33.5 & 10.0 & 11.3 & 0.5 & 1.4 & 0.79 & 44.0 \\
\hline & FAs & 23.3 & 6.6 & 23.2 & 18.6 & 7.4 & 19.6 & 0.6 & 0.7 & 0.36 & 26.6 \\
\hline \multirow{2}{*}{ OEL } & HAs & 40.7 & 8.6 & 8.9 & 18.8 & 7.1 & 12.1 & 1.7 & 2.1 & 0.38 & 27.6 \\
\hline & FAs & 25.1 & 6.4 & 18.6 & 10.3 & 4.2 & 25.0 & 3.2 & 7.2 & 0.22 & 17.7 \\
\hline \multicolumn{12}{|c|}{ Eutric Albic Stagnic Histic Retisol (Loamic) } \\
\hline \multirow{2}{*}{$\mathrm{T}$} & HAs & 23.2 & 6.0 & 11.8 & 22.4 & 8.8 & 17.0 & 4.3 & 6.5 & 0.55 & 35.5 \\
\hline & FAs & 19.5 & 2.4 & 20.2 & 12.9 & 4.2 & 26.3 & 5.1 & 9.4 & 0.29 & 22.2 \\
\hline \multirow{2}{*}{ ELg } & HAs & 50.5 & 2.8 & 7.3 & 16.9 & 4.7 & 12.8 & 2.7 & 2.3 & 0.32 & 24.3 \\
\hline & FAs & 31.2 & 2.7 & 17.9 & 8.7 & 3.3 & 27.1 & 2.5 & 6.6 & 0.17 & 14.5 \\
\hline
\end{tabular}

Comparative analysis of the molecular structure of HA and FA preparations showed that FAs are high in oxygen-containing fragment content, which explains their better water solubility and migration ability.

The high content of carboxyl groups (up to $27.1 \%$ ) determines the acidic aggressiveness of FAs in relation to soil minerals and the ability to form complex compounds with cations of iron, aluminum, and other metals converting them into soluble forms. A large amount of carbohydrate fragments (up to $23.2 \%$ ) makes FA molecules a preferable object of nutrition for soil microorganisms compared to HAs, where aliphatic chains and aromatic fragments compose more than half of their content and whose oxidation is energetically less favorable.

The evaluated content of functional groups and molecular fragments of HA indicates a significant difference in their composition in the course of transition from the organogenic horizon to the mineral one in all the soils under study. A high degree of aromaticity of HS of the upper horizons $(\mathrm{O}$ and $\mathrm{T})$ was noted in both mature Retisols.

The results obtained through ${ }^{13} \mathrm{C}$ NMR spectroscopy were compared with the data on the elemental composition of HS (Table 3). It was found that HAs contain (mol \%) $32.2-36.8 \%$ of $\mathrm{C} ; 44.6-54.1 \%$ of $\mathrm{H} ; 1.25-2.12 \%$ of $\mathrm{N}$ and $12.48-18.91 \%$ of $\mathrm{O}$. FAs are characterized by lower content of $\mathrm{C}-31.9-33.9 \%, \mathrm{H}-37.9-39.8 \%, \mathrm{~N}-0.76-1.54 \%$, and an increased share of $\mathrm{O}-26.16-27.35 \%$. 
Table 3. Distribution and elemental composition of HAs and FAs.

\begin{tabular}{|c|c|c|c|c|c|c|c|c|c|c|c|}
\hline \multirow{2}{*}{ Horizon } & \multirow{2}{*}{ HS Type } & \multirow{2}{*}{$\begin{array}{l}\text { Content, } \\
\text { g/kg Soil }\end{array}$} & \multicolumn{4}{|c|}{ Molar Content, \% } & \multicolumn{3}{|c|}{ Atomic Ratio } & \multirow{2}{*}{$(\mathrm{H} / \mathrm{C})_{\text {cor }} 1$} & \multirow{2}{*}{$\begin{array}{c}\text { Degree of } \\
\text { Oxidation } \\
(\omega)\end{array}$} \\
\hline & & & $\mathrm{C}$ & $\mathbf{H}$ & $\mathrm{O}$ & $\mathbf{N}$ & $\mathrm{H} / \mathrm{C}$ & $\mathrm{O} / \mathrm{C}$ & $\mathrm{C} / \mathrm{N}$ & & \\
\hline \multicolumn{12}{|c|}{ Eutric Albic Retisols (Loamic) } \\
\hline \multirow{2}{*}{$\mathrm{O}$} & HAs & $5.6 \pm 0.28$ & $35.6 \pm 0.4$ & $44.6 \pm 0.9$ & $17.88 \pm 0.18$ & $1.96 \pm 0.10$ & 1.25 & 0.50 & 18.2 & 1.92 & -0.08 \\
\hline & FAs & $18.2 \pm 0.9$ & $33.3 \pm 0.3$ & $39.1 \pm 0.8$ & $26.16 \pm 0.26$ & $1.42 \pm 0.07$ & 1.17 & 0.786 & 23.4 & 2.22 & +0.52 \\
\hline \multirow[b]{2}{*}{ OEL } & HAs & $6.0 \pm 0.3$ & $35.2 \pm 0.4$ & $44.7 \pm 0.9$ & $18.00 \pm 0.18$ & $2.12 \pm 0.11$ & 1.27 & 0.51 & 16.6 & 1.95 & -0.07 \\
\hline & FAs & $5.50 \pm 0.28$ & $33.0 \pm 0.3$ & $39.5 \pm 0.8$ & $26.75 \pm 0.27$ & $0.76 \pm 0.04$ & 1.20 & 0.811 & 43.4 & 2.29 & +0.49 \\
\hline \multicolumn{12}{|c|}{ Eutric Albic Retisols (Loamic) arable } \\
\hline \multirow{2}{*}{$\mathrm{O}_{\text {ara }}$} & HAs & $6.1 \pm 0.3$ & $36.8 \pm 0.4$ & $46.0 \pm 0.9$ & $15.10 \pm 0.15$ & $2.07 \pm 0.10$ & 1.25 & 0.41 & 17.8 & 1.80 & -0.26 \\
\hline & FAs & $4.23 \pm 0.21$ & $32.2 \pm 0.3$ & $39.6 \pm 0.8$ & $27.35 \pm 0.27$ & $0.83 \pm 0.04$ & 1.23 & 0.849 & 38.8 & 2.37 & +0.55 \\
\hline \multicolumn{12}{|c|}{ Eutric Albic Stagnic Histic Retisol (Loamic) } \\
\hline \multirow{2}{*}{$\mathrm{T}$} & HAs & $11.0 \pm 0.6$ & $34.5 \pm 0.3$ & $44.8 \pm 0.9$ & $18.91 \pm 0.19$ & $1.81 \pm 0.09$ & 1.30 & 0.55 & 19.1 & 2.04 & -0.04 \\
\hline & FAs & $18.3 \pm 0.9$ & $33.9 \pm 0.3$ & $37.9 \pm 0.8$ & $26.65 \pm 0.27$ & $1.54 \pm 0.08$ & 1.12 & 0.786 & 22.0 & 2.17 & +0.59 \\
\hline \multirow{2}{*}{ EL } & HAs & $8.5 \pm 0.4$ & $32.2 \pm 0.3$ & $54.1 \pm 1.1$ & $12.48 \pm 0.13$ & $1.25 \pm 0.06$ & 1.68 & 0.39 & 25.7 & 2.20 & -0.79 \\
\hline & FAs & $10.5 \pm 0.5$ & $31.9 \pm 0.3$ & $39.8 \pm 0.8$ & $27.24 \pm 0.27$ & $1.08 \pm 0.05$ & 1.25 & 0.854 & 29.5 & 2.39 & +0.56 \\
\hline
\end{tabular}

${ }^{1}(\mathrm{H} / \mathrm{C})_{\mathrm{cor}}=(\mathrm{H} / \mathrm{C})+2 \times(\mathrm{O} / \mathrm{C}) \times 0.67[7]$. 


\section{Discussion}

When comparing the molecular structure of HAs in soils with different degrees of hydromorphism, it should be noted that HAs isolated from Eutric Albic Retisol (Loamic) have a higher content of aromatic fragments compared to HAs from Eutric Albic Stagnic Histic Retisol (Loamic). In addition, an increase in the relative content of oxygen-containing functional groups $\left(-\mathrm{COOH}, \mathrm{C}_{\mathrm{Ar}}=\mathrm{O}\right.$ and $\left.-\mathrm{C}=\mathrm{O}\right)$ in $\mathrm{HA}$ molecules was noted during the transition from the $\mathrm{O}$ to OEL horizons in Eutric Albic Retisol (Loamic). The content of similar groups in the structure of HAs from Eutric Albic Stagnic Histic Retisol (Loamic), on the contrary, decreases when going from the T to OEL horizon (Table 2). The mentioned fact is explained by aerobic conditions that are formed in Eutric Albic Retisol (Loamic) and facilitate oxidation processes, while Eutric Albic Stagnic Histic Retisol (Loamic) is characterized by anaerobic conditions under which reduction processes take place.

Changes in the molecular composition of FAs in the course of the transition from automorphic to hydromorphic soils are even more apparent. Here, a trend towards an increasing degree of aromaticity of FA preparations remains in the transition from Eutric Albic Stagnic Histic Retisol (Loamic) to Eutric Albic Retisol (Loamic). The content of oxygencontaining groups also increases by $14.5 \%$ when moving from the $\mathrm{O}$ to OEL horizon in Eutric Albic Retisol (Loamic) and decreases by $5.2 \%$ in Eutric Albic Stagnic Histic Retisol (Loamic) when moving away from the T and ELg horizons.

The results obtained by us completely coincide with the data of the literature that has described the main differences between HS formed in the automorphic soils with respect to those formed in the hydromorphic environment. In particular in the case of the hydromorphic environment, HAs are comparatively: (i) more aliphatic; (ii) with low content of oxygen-containing functional groups; (iii) with a comparatively higher content of carbohydrate and protein fragments, and (iv) with a comparatively larger molecular size [22-24].

Thus, the processes of humification of plant residues in Eutric Albic Retisol (Loamic) are more intensive, which contributes to the formation of aggressive HAs enriched in oxygen-containing functional groups with a high content of aromatic fragments. HS of Eutric Albic Stagnic Histic Retisol (Loamic), by way of contrast, has a lower degree of aromaticity and mainly contains unoxidized aliphatic fragments, which, in combination with anaerobic conditions, facilitate the gleying process.

The comparative analysis of the results obtained for HAs from mature Retisols in the European northeast of Russia and data on the structural composition of HS isolated from soils of other climatic zones showed that the studied HA preparations are richer in aromatic structures compared to Spodic Cryosols and are lower in aromatic structure content in comparison with the soils of the southern regions, such as Phaeozems and Chernozems [25-27]. The indicated regularities of the structural composition of HAs are associated with the rate of humification processes: in the northern regions these processes are slower, and in the southern regions they are more intensive, while HS is more "mature" [7,20].

It has been found that with a higher degree of humification of HAs in the mineral horizons their oxidation degree increases. A decreased oxidation state of FAs from Eutric Albic Retisol (Loamic) and an increased one from Eutric Albic Stagnic Histic Retisol (Loamic) has been observed, while HAs show quite the opposite. This feature can be explained based on the intensity of microbiological activity being a driver for HAs formation. With more intense biological activity, there is the rapid destruction of non-specific compounds, such as proteins and carbohydrates $[19,27,28]$. Therefore, the higher biochemical activity of Eutric Albic Retisol (Loamic) in comparison with Eutric Albic Stagnic Histic Retisol (Loamic) [29] contributes to the oxidation of HA molecules with an accumulation of the most stable oxygen-containing products. Under similar conditions, FAs are one of the most accessible media for soil microorganisms and therefore they are rapidly used by them and get renewed. As a result, FAs from Eutric Albic Retisol (Loamic) are the youngest and least oxidized. The literature also contains data on an increase in the oxygen content during HA "maturation" [30,31]. 
A decrease in the $\mathrm{C} / \mathrm{N}$ ratio in the HAs isolated from Albic Retisols (Loamic) indicates an increase in the proportion of whole nitrogen content, associated with protein fragments. Thus, the nitrogen content in the HAs could be an indicator of acrogenic soil transformation in long-term scenarios.

The Van Krevelen graphical statistical analysis also demonstrates higher oxidation and lower carbon content of FAs compared to HAs (Figure 1), which indicates a significant substitution of aromatic rings and the development of side aliphatic chains [32,33].

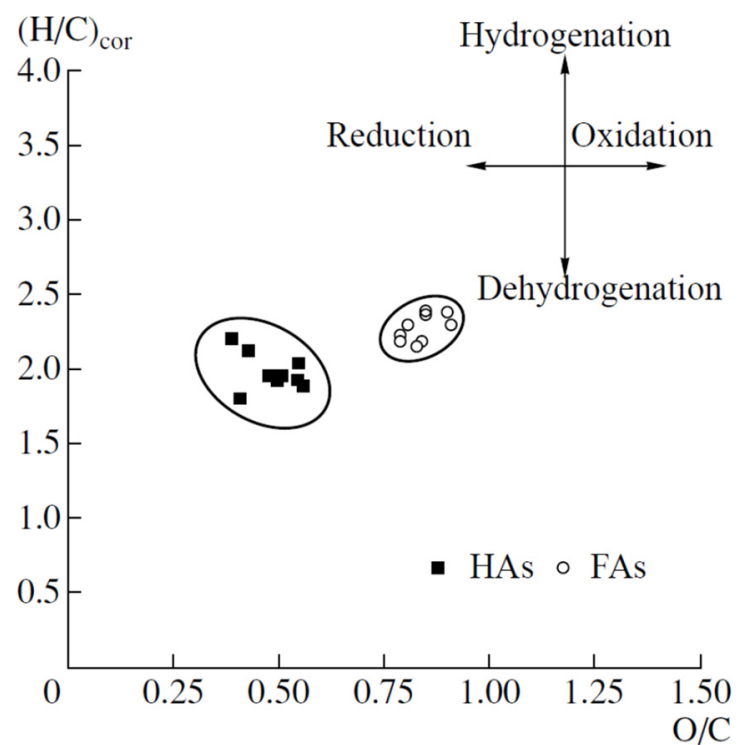

Figure 1. Distribution of preparations by atomic ratio in the $(\mathrm{H} / \mathrm{C})_{\mathrm{cor}}-\mathrm{O} / \mathrm{C}$ coordinates.

The elemental composition of HAs from various Retisols is comparatively well studied, and our results agree with the known data for soils of the boreal zone $[1,7,34]$.

To study the effect of agricultural development on the structural and functional composition of HS by ${ }^{13} \mathrm{C}$ NMR spectroscopy (CPMAS technique), preparations of HAs from the $\mathrm{O}_{\text {ara }}$ horizon of the arable Eutric Albic Retisol (Loamic) were studied (Figure 2). The influence of soil development on the relative content of functional groups and molecular fragments of HAs is shown in Figure 3.

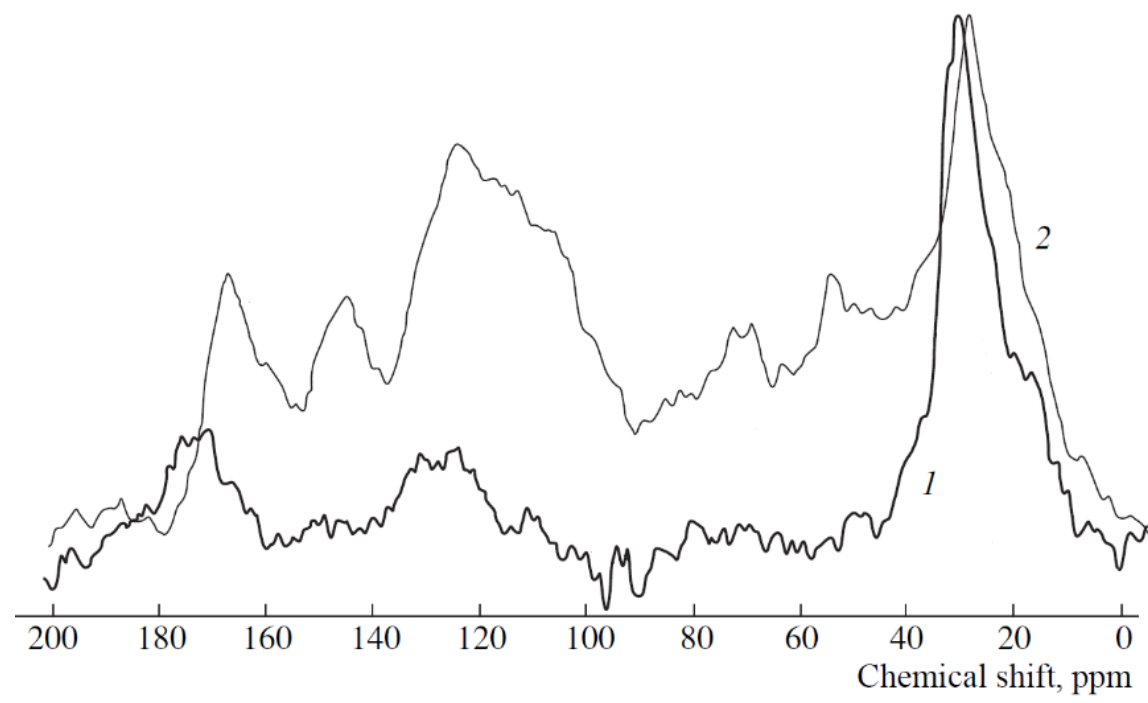

Figure 2. CPMAS ${ }^{13} \mathrm{C}$ NMR spectra of HAs from mature (1) and arable (2) Retisols. 


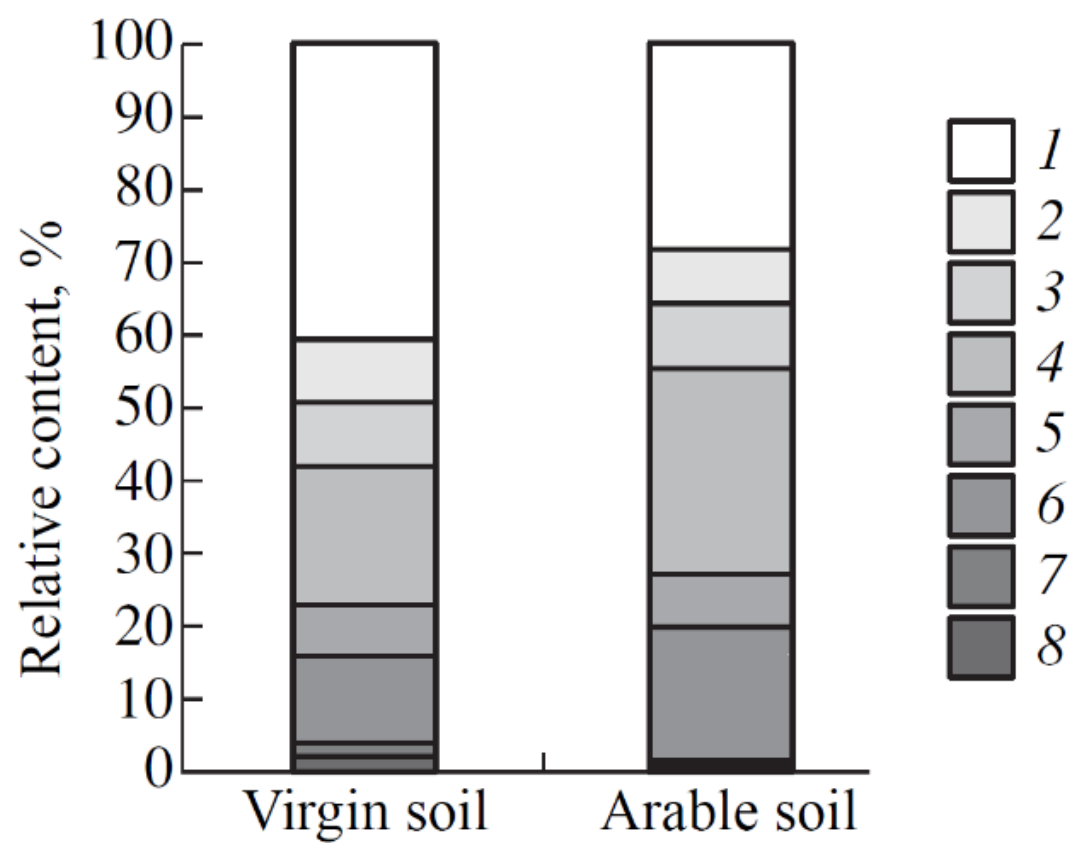

Figure 3. Relative content of structural fragments in HAs from mature and arable Retisols: aliphatic $-\mathrm{CH},-\mathrm{CH}_{2}$, and $-\mathrm{CH}_{3}$ groups (1); amino group $\mathrm{C}$ and $-\mathrm{O}-\mathrm{CH}_{3}$ structures (2); carbohydrate, alcohol, and ether $-\mathrm{C}-\mathrm{O}$ groups (3); aromatic $\mathrm{C}(4)$; phenol $\mathrm{C}_{\mathrm{Ar}}-\mathrm{O}(5) ;-\mathrm{COOH}$ groups (6); quinone $\mathrm{C}_{\mathrm{Ar}}=\mathrm{O}$ (7) and aldehyde and ketone $-\mathrm{C}=\mathrm{O}$ groups (8).

When comparing the data on the structure of HAs from mature and arable Eutric Albic Retisols (Loamic) (Figures 2 and 3), a relative decrease in the total amount of aliphatic chains accompanied by an $8.4 \%$ increase in the content of aromatic structures should be noted, which subsequently leads to an increase in the $\Sigma \mathrm{C}_{\mathrm{Ar}} / \Sigma \mathrm{C}_{\mathrm{AL}}$ ratio in arable soil by half. It was found that plowing results in a decrease in -C-O groups of alcohols, ethers, and carbohydrates in the structure of HAs. It is explained by the fact that agricultural use enhances microbiological activity, which in turn leads to the destruction of the easily hydrolyzable part of HS consisting mainly of carbohydrate fragments [26].

The findings of the elemental analysis of the HAs from the arable Eutric Albic Retisol (Loamic) also confirm that agricultural development leads to an increased proportion of aromatic fragments, which is expressed as a lower $(\mathrm{H} / \mathrm{C})$ cor ratio compared to the mature soil samples (Table 3). Literature data also indicate a significant transformation of the carbon skeleton of HA macromolecules manifested in a relative increase in the total content of aromatic structures as a result of agricultural use [5,22,35].

\section{Conclusions}

The following functional groups and molecular fragments have been identified in the structure of HS: carboxylic; carbonyl; aliphatic; alcohols, ethers, and carbohydrates; phenolic; quinone; and aromatic ones. It was found that aliphatic structures prevail in the FA composition, while HA is dominated by aromatic structures.

Excessive moisture does not only affect the amount of accumulated HS, but also their molecular structure, namely, by causing accumulation of HS enriched with aliphatic structures in the semi-hydromorphic Eutric Albic Stagnic Histic Retisol (Loamic). The presence of a significant amount of unoxidized aliphatic fragments in the HAs structure from Eutric Albic Stagnic Histic Retisol (Loamic) is due to anaerobic conditions.

Agricultural development of Eutric Albic Retisols (Loamic) leads to the transformation of the molecular structure of HS, which manifests itself in a relatively higher proportion of aromatic molecular fragments and a decreased amount of carbonyl groups, which makes HAs less acidic and facilitates their accumulation in the arable horizon. 
Author Contributions: Conceptualization, E.L.; methodology, E.L. and E.A.; software, E.L.; validation, E.L. and E.A.; formal analysis, E.L. and E.A.; investigation, E.L. and E.A.; resources, E.L. and E.A.; data curation, E.L. and E.A.; writing-original draft preparation, E.L.; writing-review and editing, E.A.; visualization, E.L.; supervision, E.A.; project administration, E.L.; funding acquisition, E.L. and E.A. All authors have read and agreed to the published version of the manuscript.

Funding: The reported study was funded by the Federal budget of Russia (Topic of Institute of Biology) and RFBR grant (no. 19-05-50107).

Institutional Review Board Statement: Not applicable.

Informed Consent Statement: Not applicable.

Data Availability Statement: Not applicable.

Conflicts of Interest: The authors declare no conflict of interest. The funders had no role in the design of the study; in the collection, analyses, or interpretation of data; in the writing of the manuscript; or in the decision to publish the results.

\section{References}

1. Kechaikina, I.O.; Ryumin, A.G.; Chukov, S.N. Postagrogenic transformation of organic matter in soddy-podzolic soils. Eurasian Soil Sci. 2011, 44, 1077-1089. [CrossRef]

2. Lehmann, J.; Kleber, M. The contentious nature of soil organic matter. Nature 2015, 528, 60-68. [CrossRef]

3. Hayes, M.H.B.; Swift, R.S. Chapter one-Vindication of humic substances as a key component of organic matter in soil and water. Adv. Agron. 2020, 163, 1-37. [CrossRef]

4. Swift, R.S. Organic matter characterization. In Methods of Soil Analysis: Part 3 Chemical Methods, 5.3; Sparks, D.L., Page, A.L., Helmke, P.A., Loeppert, R.H., Soltanpour, P.N., Tabatabai, M.A., Johnston, C.T., Sumner, M.E., Eds.; Soil Science Society of America: Madison, WI, USA, 1996; pp. 1018-1020. [CrossRef]

5. Guo, X.; Liu, H.; Wu, S. Humic substances developed during organic waste composting: Formation mechanisms, structural properties, and agronomic functions. Sci. Total Environ. 2019, 662, 501-510. [CrossRef]

6. Koković, N.; Saljnikov, E.; Eulenstein, F.; Čakmak, D.; Buntić, A.; Sikirić, B.; Ugrenović, V. Changes in soil labile organic matter as affected by 50 years of fertilization with increasing amounts of nitrogen. Agronomy 2021, 11, 2026. [CrossRef]

7. Orlov, D.S. Humic Substances of Soils and General Theory of Humification, 1st ed.; Taylor \& Francis: London, UK, 1995; 325p. [CrossRef]

8. Lentz, H.; Lüdemann, H.D.; Ziechmann, W. Proton resonance spectra of humic acid from the solum of a podzol. Geoderma 1973, 18, 325-328. [CrossRef]

9. Lodygin, E.; Shamrikova, E. Use of the pK spectroscopy method in the study of protolytic properties of humic substances and other soil polyelectrolytes. Agronomy 2021, 11, 1051. [CrossRef]

10. Ndzelu, B.S.; Dou, S.; Zhang, X.; Zhang, Y.; Ma, R.; Liu, X. Tillage Effects on humus composition and humic acid structural characteristics in soil aggregate-size fractions. Soil Tillage Res. 2021, 216, 105090. [CrossRef]

11. Volkov, D.S.; Rogova, O.B.; Proskurnin, M.A. Temperature dependences of IR spectra of humic substances of brown coal. Agronomy 2021, 11, 1822. [CrossRef]

12. Fründ, R.; Lüdemann, H.D. The quantitative analysis of solution- and CPMAS-C-13 NMR spectra of humic material. Sci. Total Environ. 1989, 81/82, 157-168. [CrossRef]

13. Wershaw, R.L.; Leenheer, J.A.; Kennedy, K.R.; Noyes, T.I. Use of ${ }^{13} \mathrm{C}$ NMR and FTIR for elucidation of degradation pathways during natural litter decomposition and composting I. early stage leaf degradation. Soil Sci. 1996, 161, 667-679. [CrossRef]

14. Wilson, M.A. Application of nuclear magnetic resonance spectroscopy to the study of the structure of soil organic matter. Soil Sci. 1981, 32, 167-186. [CrossRef]

15. Lodygin, E.D.; Beznosikov, V.A.; Chukov, S.N. Paramagnetic properties of humus acids of podzolic and bog-podzolic soils. Eurasian Soil Sci. 2007, 40, 726-728. [CrossRef]

16. Chukov, S.N.; Lodygin, E.D.; Abakumov, E.V. Application of ${ }^{13} \mathrm{C}$ NMR spectroscopy to the study of soil organic matter: A review of publications. Eurasian Soil Sci. 2018, 51, 889-900. [CrossRef]

17. Al-Faiyz, Y.S.S. CPMAS ${ }^{13} \mathrm{C}$ NMR characterization of humic acids from composted agricultural saudi waste. Arab. J. Chem. 2017, 10, S839-S853. [CrossRef]

18. Savarese, C.; Drosos, M.; Spaccini, R.; Cozzolino, V.; Piccolo, A. Molecular characterization of soil organic matter and its extractable humic fraction from long-term field experiments under different cropping systems. Geoderma 2020, 383, 114700. [CrossRef]

19. Sarker, T.C.; Incerti, G.; Spaccini, R.; Piccolo, A.; Mazzoleni, S.; Bonanomi, G. Linking organic matter chemistry with soil aggregate stability: Insight from ${ }^{13} \mathrm{C}$ NMR spectroscopy. Soil Biol. Biochem. 2017, 117, 175-184. [CrossRef]

20. Lodygin, E.; Vasilevich, R. Environmental aspects of molecular composition of humic substances from soils of northeastern European Russia. Polish Polar Res. 2020, 41, 115-135. [CrossRef] 
21. Preston, C.M. Using NMR to characterize the development of soil organic matter with varying climate and vegetation. In Stable Isotopes in Plant Nutrition. Soil Fertility and Environmental Studies; Proceedings Series; International Atomic Energy Agency: Vienna, Austria, 1991; pp. 27-36.

22. Rodríguez-Murillo, J.C.; Almendros, G.; Knicker, H. Humic acid composition and humification processes in wetland soils of a mediterranean semiarid wetland. J. Soils Sediments 2017, 17, 2104-2115. [CrossRef]

23. Savel'eva, A.V.; Yudina, N.V.; Inisheva, L.I. Characteristics of humic acids in a system of geochemically linked bog landscapes. Solid Fuel Chem. 2020, 54, 253-259. [CrossRef]

24. Szajdak, L.W.; Jezierski, A.; Wegner, K.; Meysner, T.; Szczepánski, M. Influence of drainage on peat organic matter: Implications for development, stability, and transformation. Molecules 2020, 25, 2587. [CrossRef]

25. Chukov, S.N. Study of humus acids in anthropogenically disturbed soils using ${ }^{13}$ C-NMR spectroscopy. Eurasian Soil Sci. 1998, 31, 979-986.

26. Danchenko, N.N.; Artemyeva, Z.S.; Kogut, B.M. Features of the chemical structure of different organic matter pools in haplic chernozem of the streletskaya steppe: ${ }^{13} \mathrm{C}$ MAS NMR study. Environ. Res. 2020, 191, 110205. [CrossRef] [PubMed]

27. Polyakov, V.; Loiko, S.; Istigechev, G.; Lapidus, A.; Abakumov, E. Elemental and molecular composition of humic acids isolated from soils of tallgrass temperate rainforests (Chernevaya taiga) by ${ }^{1} \mathrm{H}_{-}{ }^{13} \mathrm{C}$ HECTCOR NMR spectroscopy. Agronomy 2021, 11, 1998. [CrossRef]

28. Shamrikova, E.V.; Kubik, O.S.; Deneva, S.V.; Punegov, V.V. Composition of the water-soluble soil fraction on the barents sea coast: Organic carbon and nitrogen, low-molecular weight components. Eurasian Soil Sci. 2019, 52, 1347-1362. [CrossRef]

29. Khabibullina, F.M.; Kuznetsova, E.G.; Vaseneva, I.Z. Micromycetes in podzolic and bog-podzolic soils in the middle taiga subzone of Northeastern European Russia. Eurasian Soil Sci. 2014, 47, 1027-1032. [CrossRef]

30. Kholodov, V.A.; Yaroslavtseva, N.V.; Konstantinov, A.I.; Perminova, I.V. Preparative yield and properties of humic acids obtained by sequential alkaline extractions. Eurasian Soil Sci. 2015, 48, 1101-1109. [CrossRef]

31. Lodygin, E.D.; Beznosikov, V.A.; Vanchikova, E.V. Functional groups of fulvic acids from gleyic peaty-podzolic soil. Eurasian Soil Sci. 2001, 34, 382-386.

32. Dergacheva, M.I.; Nekrasova, O.A.; Okoneshnikova, M.V.; Vasil'eva, D.I.; Gavrilov, D.A.; Ochur, K.O.; Ondar, E.E. Ratio of Elements in humic acids as a source of information on the environment of soil formation. Contemp. Probl. Ecol. 2012, 5, $497-504$. [CrossRef]

33. Lodygin, E.D.; Beznosikov, V.A. The molecular structure and elemental composition of humic substances from Albeluvisols Chem. Ecol. 2010, 26, 87-95. [CrossRef]

34. Kukul,s, I.; Klaviňš, M.; Nikodemus, O.; Kasparinskis, R.; Brūmelis, G. Changes in soil organic matter and soil humic substances following the afforestation of former agricultural lands in the boreal-nemoral ecotone (Latvia). Geoderma Reg. 2019, 16, e00213. [CrossRef]

35. Slepetiene, A.; Volungevicius, J.; Jurgutis, L.; Liaudanskiene, I.; Amaleviciute-Volunge, K.; Slepetys, J.; Ceseviciene, J. The potential of digestate as a biofertilizer in eroded soils of Lithuania. Waste Manag. 2020, 102, 441-451. [CrossRef] [PubMed] 